\title{
Inhalt, Vol. 8, No. 4, 1985
}

\section{Contents}

Impressum

194

Dunzendorfer, U. und Knöner, M., Frankfurt/M.

Therapie mit Inhibitoren der Polyaminbiosynthese beim refraktären Prostatakarzinom. - Eine experimentelle und klinische Studie 196

Ehninger, G. undHaag, C, Tubingen; Ruckle, H. und Wilms, K., Würzburg

Die Therapie der Peritonealkarzinose mit intraperitonea-

ler Gabe von cis-Diaminodichloroplatin und systemischer

Natriumthiosulfatprotektion. - Klinische Ergebnisse

einer Pilotstudie und Pharmakokinetik 202

Gatzemeier, U.; Hossfeld, D. K.; Radenbach, D. und Zschaber, R., Hamburg

Chemotherapie mit Mitomycin C, Vindesin und Ifosfa-

mid in der Behandlung des inoperablen nicht-kleinzelli-

gen Bronchialkarzinoms 208

Neuigkeiten für die klinische Praxis 213

Gerhartz, H. undJehn, U., München

Granulozytäre Vorläuferzellen bei akuter Leukämie:

Vergleich zwei verschiedener Kulturmethoden

Buchbesprechungen 218

Herschbach, P.; Rosbund, A.-M. und

Brengelmann, J. C. , München

Probleme von Krebspatientinnen und Formen ihrer Be-

wältigung 219

Maier, U. und Holzner, J. H., Wien

Stellenwert der Urotheldysplasien in makroskopisch nor-

maler Schleimhaut bei Patienten mit Blasentumoren. -

Ergebnis einer randomisierten Studie mit und ohne intra-

vesikaler Mitomycin-C-Rezidivprophylaxe 232

Lellé, R. J.; Heidenreich, W. und Peter, H. H., Hannover Lymphoide Zellen im Venenblut von 100 Patientinnen mit Mammakarzinom. - Eine Verlaufsbeobachtung . . . 241

Hinweise für Autoren 245

Onkologie-Mitteilungen 246

Imprint194

Dunzendorfer, U. and Knöner, M., Frankfurt/M.

Therapy with Inhibitors of Polyamine Biosynthesis in

Hormone-Resistant Prostate Cancer 196

Ehninger, G. andHaag, C, Tubingen; Ruckle, H. and Wilms, K., Würzburg 
Intraperitoneal Cis-Dichlorodiammineplatinum and Systemic Sodium Thiosulfate Protection in Peritoneal Carcinosis. - Clinical and Pharmacokinetic Data of a Pilot-Study 202

Gatzemeier, U.; Hossfeld, D. K.; Radenbach, D. and Zschaber, R., Hamburg Combination Chemotherapy with Mitomycin C, Vindesine, and Ifosfamide in the Treatment of Inoperable NonSmall-Cell Lung Cancer 208 News for Clinical Practice 213 Gerhartz, H. andJehn, U., München Granulopoietic Progenitor Cells (CFU-C) in Patients with Acute Leukemia: A Comparison of Two Different Culture Techniques 214

Book Reviews 218

Herschbach, P.; Rosbund, A.-M. and

Brengelmann, J. C, München

Psychosocial Problems and Coping Strategies of Female

Cancer Patients 219

Maier, U. and Holzner, J. H., Wien The Value of Urothelial Dysplasias in Normal Looking Bladder Mucosa from Patients with Bladder Tumors. -Results of a Prospective Study with and without Prophylactic Intravesical Chemotherapy with Mitomycin C . . 232

Lellé, R. J.; Heidenreich, W. and Peter, H. H., Hannover

Lymphoid Cells in the Venous Blood of 100 Breast

Cancer Patients 241

Instructions for Authors 245

Oncology Communications 246

Bibliographischer Hinweis: Inhaltsverzeichnisse dieser Zeitschrift erscheinen regelmäßig in current contents ${ }^{\circledR}$ sowie in anderen bibliographischen Diensten. 